\title{
DESIGN THINKING HADIS HUKUM PELAKSANAAN AQIQAH UNTUK KEPATUHAN PADA PROTOKOL KESEHATAN PANDEMI COVID-19
}

\author{
Wahyudin Darmalaksana \\ Jurusan Ilmu Hadis, Fakultas Ushuluddin, UIN Sunan Gunung Djati Bandung \\ Email : yudidarma@uinsgd.ac.id
}

\begin{abstract}
The implementation of aqiqah is a highly recommended sunnah for Muslim families who receive the gift of a newborn. However, implementing aqiqah in the midst of the Covid-19 pandemic requires adherence to health protocols. This study aims to design the implementation of the sunnah aqiqah during the Covid19 pandemic. This research method uses a qualitative type through literature study and field studies with a design thinking approach. The results and discussion of this study include the design of the aqiqah implementation room, the meaning of the essence of the hadith of aqiqah in line with the prevention of infectious epidemics, and the design of the aqiqah ritual according to the expectations of Muslim family couples who are gifted with newborns by implementing a new life order without eliminating the wisdom of Islamic law as compliance with protocol. health Covid-19. This research concludes that the prototype of the implementation of aqiqah can basically be designed with the demands of new conditions but does not conflict with Islamic law principles. The recommendation of this research is that a new approach to design thinking needs a touch of development in Islamic scholarship.
\end{abstract}

Keywords: Aqiqah, Covid-19, Design thinking, Pregnancy Fiqh, Legal hadith

\begin{abstract}
ABSTRAK
Pelaksanaan aqiqah merupakan sunnah yang sangat dianjurkan untuk keluarga muslim yang mendapat anugerah bayi baru lahir. Namun, pelaksanaan aqiqah di tengah pandemic Covid -19 mensyaratkan kepatuhan terhadap protokol kesehatan. Penelitian ini bertujuan mendesain pelaksanaan sunnah aqiqah pada masa pandemi Covid-19. Metode penelitian ini menggunakan jenis kualitatif melalui studi pustaka dan studi lapangan dengan pendekatan design thinking. Hasil dan pembahasan penelitian ini meliputi desain ruang pelaksanaan aqiqah, pemaknaan esensi kandungan hadisaqiqah sejalan dengan pencegahan wabah menular, dan perancangan ritual aqiqah sesuai harapan pasangan keluarga muslim yang dianugerahi bayi baru lahir dengan menerapkan tatanan kehidupan baru tanpa menghilangkan hikmah hukum Islam sebagai kepatuhan terhadap protokol kesehatan Covid-19. Penelitian ini menyimpulkan bahwa prototipe pelaksanaan aqiqah pada dasarnya dapat dirancang dengan tu ntutan keadaan baru tetapi tidak bertentangan dengan kaidah hukum Islam. Rekomendasi penelitian ini adalah, pendekatan baru design thinking perlu mendapat sentuhan pengembangan dalam keilmuan Islam.
\end{abstract}

Kata Kunci: Aqiqah, Covid-19, Design thinking, Fiqih kehamilan, Hadis hukum

\section{PENDAHULUAN}

Hadis mengajurkan pelaksanaan aqiqah bagi pasangan keluarga muslim yang dianugerahi bayi baru lahir (Arifin, 2014). Hadis, yang juga lazim disebut sunnah (Darmalaksana, 2020d; Soetari, 1994), berfungsi sebagai petunjuk bagi umat manusia (Thantowi, 1994). Bagi keluarga muslim yang taat pada pentunjuk Islam, serta mampu secara ekonomi, pasti sangat mengharapkan dapat telaksananya aqiqah. Namun, sejak akhir tahun 2019, umatmanusiasedang dilanda pandemi coronavirus disease yang disingkat Covid-19 (Fauci et al., 2020). Suatu prosesi keagamaan di masa Covid-19, tentu termasuk pelaksanaan

* Copyright (c) 2020 Wahyudin Darmalaksana

This work is licensed under a Creative Commons Attribution-ShareAlike 4.0 International License. 
aqiqah, dibutuhkan protokol kesehatan (Shodiqin et al., 2020) dan sekaligus design thinking untuk mengatasi masalah (Henriksen etal.,2017).

Sejak akhir tahun 2019, pandemi Covid-19 menyebar secara global di 216 negara yakni terkonfirmasi 17.660.523 dan meninggal 680.894, sedangkan di Indonesia positif 214.746, sembuh 152.458, dan meninggal 8.650. Ini merupakan data terkini dari Satuan Tugas Penanganan Covid-19, Sabtu, 12 September 2020 (Tugas, 2020). Virus Corona dapat menyerang siapa saja mulai dari bayi, anak-anak, orang dewasa hingga lanjut usia (Siagian, 2020). Kelompok lanjut usia (lansia) menjadi kelompok paling berisiko menularkan dan tertular virus (Pradana \& Casman, 2020). Penyebaran virus Corona dapat disebabkan oleh adanya kerumunan (Yunus \& Rezki, 2020). Termasuk kerumunan di tempat-tempat ibadah dalam kegiatan keagamaan (Nasution \& Wijaya, 2020). Pemerintah melarang adanya kerumunan di masa Covid-19 (Solahudin etal., 2020). Terbitpula fiqih Corona (Hasbiyallah et al., 2020) yang dilandasi berbagai fatwa Majelis Ulama Indonesia (MUI) terkait protokol Covid bagi umat Islam (Saeful, 2020).

Terdapat hadis Nabi Saw. berkenaan dengan antisipasi pencegahan wabah penyakit menular (Darmalaksana, 2020a). Di antaranya hadis yang menyatakan tentang larangan memasuki suatu negeri yang sedang terjangkit wabah menular, dan larangan tidak boleh keluar dari negeri tersebut bagi mereka yang sedang berada di dalamnya (Nasir, 1422). Hadis ini beserta hadis lainnyayang satu tema dengan ini (Khaeruman et al., 2020) merupakan hadis yang populer dan dijadikan rujukan dalam antisipasi pencegahan wabah Covid-19 (Mardiana \& Darmalaksana, 2020). Pada saat yang sama terdapat hadishadis tentang anjuran pelaksanaan aqiqah bagi pasangan keluarga muslim yang dianuerahi bayi baru lahir (Arifin, 2014). Menurut para ulama, aqiqah merupakan sunnah muakadah yaitu sunnah yang sangat dianjurkan (Galuh Abdi Sucipto, 2018). Rangkaian sunnah dalam aqiqah biasanya meliputi penyembelihan hewan kambing (Zainuddin \& Azkia, 2017), pemberian nama (Maulidiyah, 2015), dan mencukur rambut bayi (Azizah, 2019).

Beberapa kajian terdahulu tentang aqiqah seperti penelitian yang dilakuakan oleh Al-Kasyairi (2015) meneliti tentang nilai - nilai Pendidikan dalam hadist ibadah aqiqah, Ilmiyyah (2016) meneliti tentang pemahan impelementasi hadist-hadist aqiqah pada suatu desa di kota kudus, dan beberapa penellitian lainnya tentang nilai - nilai Pendidikan islam pada aqiqah (Mualimin, 2015; Septianingsih, 2018) adapun penelitian aqiqah tentang hukum belum ada yang meneliti tentang hukum aqiqah dalam menjaga kepatuhan terhadap protocol COVID-19. Hal ini menjadi penting karena bagi negara yang terdampak pandemi COVID-19 dibutuhkannya suatu penelitian - penelitian, berdasarkan teoridan konsep yang jelas yang nantinya akan dibahas pada penelitian ini.

Berdasarkan paparan di atas, penalaran logis penelitian ini adalah terdapat hadis Nabi Saw. berkenaan dengan anjuran pelaksanaan aqiqah dan terdapat hadis Nabi Saw tentang antisipasi pencegahan wabah penyakit menular. Pertanyaannya ialah, bagaimana design thinking pelaksanaan sunnah aqiqah pada masa pandemi Covid-19. Penelitian ini bertujuan mendesain pelaksanaan sunnah aqiqah pada masa pandemi Covid-19. Penelitian ini diharpakan bermanfaat, khususnya bagi pasangan keluarga muslim yang bermaksud melaksanakah aqiqah di masa Covid-19.

\section{METODE PENELITIAN}

Penelitianini merupakan jenis kualitatif melalui studi pustakadan studi lapangan (Darmalaksana, 2020b) dengan pendekatan design thinking (Darmalaksana, 2019). Adapun pendekatan design thinking meliputi beberapa fase pelaksanaan penelitian, yakni empathize, define, ideate, prototype, dan test (Henriksen et al.,2017). 


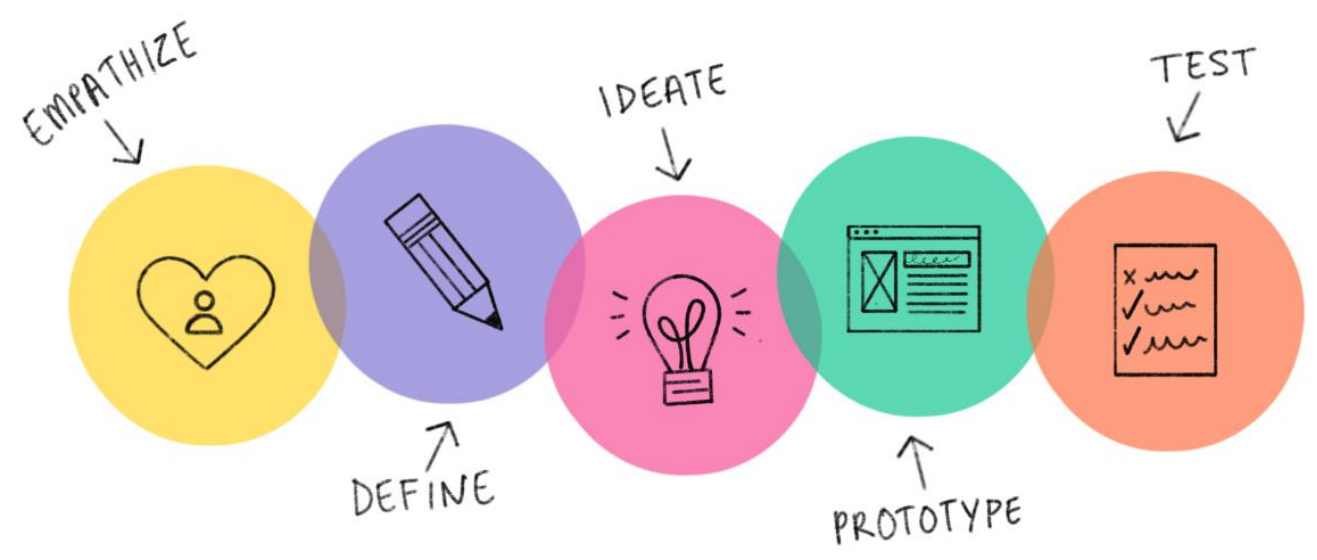

\section{Gambar 1. Pendekatan Design Thinking}

Gambar 1 merupakan pendekatan design thinking yang mencakup beberapa fase dengan penjelasan masing-masing komponenutama dibawah ini (Steinke et al.,2018):

\section{Epathize}

Fase empati untuk memahami masalah yang dihadapi penerima manfaat atau pengguna hasil penelitian. Empati mensyaratkan beberapa proses, seperti mengamati, keterlibatan melalui percakapan, dan wawancara yang dilakukan secara mendalam. Tujuan dari fase ini untuk memahami masalah yang dialami pengguna (Steinke et al, 2018).

\section{Define}

Fase mendefinisikan untuk menghasilkan fokuskejelasan masalah. Peneliti menerapkan kekuatan berpikir untuk memahami masalah yang dialami oleh pengguan. Setelah masalah dipahamidengan jelas, peneliti dapat pindah ke tahap berikutnya untuk menghasilkan ide mengatasi masalah. Fase definisi diakhiri dengan ditetapkan secara jelas tentang ruang lingkup dan parameter masalah (Steinke et al., 2018).

\section{Ideate}

Fase ideate diarahkan untukmenghasilkan ide-ideyang bisa menjadi solusi dari masalah yang telah didefinisikan sebelumnya. Peneliti memungkinkan menggunakan imajinasi untukmenghasilkan berbagai ide yang mengarah ke inovasi. Fase ideating mencakup bergam teknik inovasi, termasuk membangun prototipe, pemetaan pikiran, dan membuat sketsa. Terutama pembuatan prototipe dengan pandangan baru sebagai solusi (Steinke etal., 2018).

\section{Prototype}

Fase membuat prototipe dari ide inovasi hingga produk terwujud. Semakin realistis ideprototipe, maka semakin baik untuk diwujudkan. Peneliti memungkinkan mengenali kekurangan prototipe untuk desain yanglebih inovatif sehingga mereka dapat mengulangi pembuatan produkyang lebih baik (Steinke et al., 2018).

5. $\quad$ Test

Fase pengujian merupakan cara untuk umpan balik dari prototipe yang dibuat sebelumnya. Pengujian memungkinkan mengulangi proses empati dengan penggunasecara lebih diharapkan. Umpan 


\section{Khazanah Hukum, Vol. 2 No. 3: 100-109}

Design Thinking Hadis Hukum Pelaksanaan Aqiqah Untuk Kepatuhan pada Protokol Kesehatan Pandemi COVID-19

Wahyudin Darmalaksana

balik dari fase pengujian ini akan membantu penyempurnaan prototipe, hingga dipastikan bahw a masalah ditangani dengan tepat (Steinke et al.,2018).

\section{HASIL DAN PEMBAHASAN}

\section{Desain Ruang Pelaksanaan Aqiqah}

Pasangan keluarga muslim yang taat pada ajaran Islam dipastikan berniat melaksanakan sunnah aqiqah bagi yang mampu secara ekonomi. Kata 'aqiqah' berasal dari Bahasa Arab yang dalam serapan Bahasa Indonesia disebut 'akikah' (Setiawan, 2020). Akikah biasanya merupakan penyembelihan ternak, seperti kambing atau lembu, sebagai pernyataan syukur orang tua atas kelahiran anaknya, lazimnya dilaksanakan pada hari ketujuh; tradisi penyembelihan ternak pada upacara pencukuran rambut bayi ketika berusia tujuh hari sebagai pernyataan syukur (Setiawan, 2020). Bermula dariserapan Bahasa Arab, akikah telah menjadi tradisi pada keluarga muslim di Indonesia (Angkola, 2019).

Sebagai sunnah yang sangat dianjurkan (Galuh Abdi Sucipto, 2018), aqiqah sangat diharapkan oleh pasangan keluarga muslim untukpenyambut kelahiran SangBayi (Tsaury, 2001), meskipun berada dalam kondisi pandemi Covid-19. Tentu, pelaksanaan aqiqah mensyaratkan protokol kesehatan Covid-19, sehingga berdasarkan design thinking dihasilkan tataruang pelaksanaan aqiqah

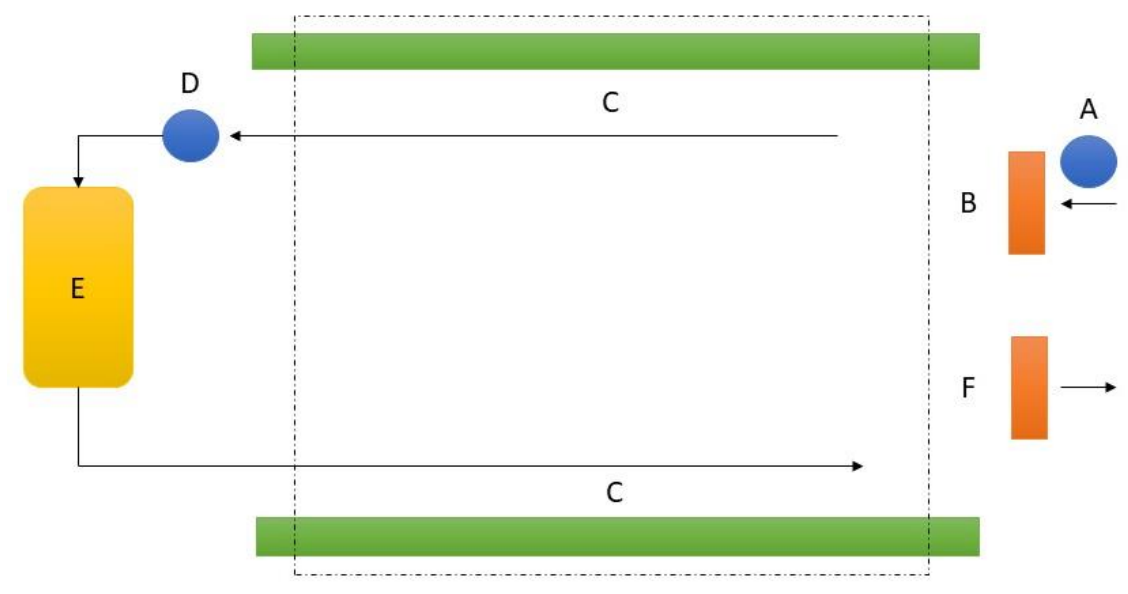

\section{Gambar 2. Desain Ruang Aqiqah}

Keterangan:

$A=$ Hand sanitizer \& termometer digital

$\mathrm{B}=$ Pintumasuk

$\mathrm{C}=$ Jama'ah pengajian

$\mathrm{D}=$ Hand sanitizer

$\mathrm{E}=$ Ruang bayi

$\mathrm{F}=$ Pintukeluar

Gambar 2 menunjukan desain ruang pelaksanaan aqiqah. Tanda A merupakan tempat hand sanitizer dan termometer digital untuk mengecek suhu tubuh jama'ah pengajian. Tanda B merupakan pintu masuk jama'ah pengajian untuk pelaksanaan aqiqah. Tanda $\mathrm{C}$ merupakan tempat jama'ah untuk pelaksanaan pengajian. Tanda $\mathrm{D}$ adalah tempat hand sanitizer untuk petugas yang telah ditunjuk untuk 


\section{Khazanah Hukum, Vol. 2 No. 3: 100-109}

Design Thinking Hadis Hukum Pelaksanaan Aqiqah Untuk Kepatuhan pada Protokol Kesehatan Pandemi COVID-19

Wahyudin Darmalaksana

pencukuran rambut bayi. TandaE ialah ruang khusus bayi dan ibu bayi. Adapun tanda F merupakan pintu keluar jama'ah pengajian.

\section{Sunnah Aqiqah dan Pencegahan Wabah}

Hadis tentang aqiqah tersebar dalam kitab-kitab hadis. Di antaranya dalam Kitab al-Jami' al-Shahih karya Imam al-Bukhari sebagai hadis dengan sanad yang kuat (Makmun, 2015) juga di dalam Kitab Sunan An-Nasa'i (Suaibah,1997). Dari Samurah bin Jundub, Nabi Saw.bersabda:

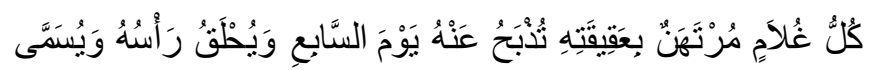

Artinya: "Setiap anak tergadaikan dengan aqiqahnya, [hewan kambing] disembelih pada hari ketujuh, dicukur plontos rambutnya, dan diberi nama" (HR. Ahmad, at-Turmudzi, dan disahihkan al-Albani).

Para ulama telah melakukan berbagai studi terhadap hadis-hadis tentang aqiqah (Ritonga \& Ritonga, 2013), baik studi sanad maupun studi matan (Makmun, 2015). Hadis aqiqah dari segi sanad dinilai bersambung dan dari segi matan tidak ada cacat sehingga hadis tentang aqiqah dinilai sahih (Makmun, 2015). Karena itu, aqiqah dinilai sebagai sunnah yang sangat dianjurkan (Galuh Abdi Sucipto, 2018). Dari aspek kajian matan hadis, aqiqah secara tegas menganjurkan penyembelihan hewan (Siregar, 2013). Aqiqah dilaksanakan pada hari ke 7 (tujuh), atau hari ke 14, atau hari ke 21 (Said, 1995). Bagi keluarga muslim yang mampu secara ekonomi, disunahkan menyembelih kambing (Erizal, 2019), pejantan atau betina (Zainuddin \& Azkia, 2017). Bagi anak laki-laki 2 (dua) ekor kambing dan bagi anak perempuan 1 (satu) ekor kambing (Erizal, 2018).

Selain penyembelihan hewan (Restianti, 2013), pemberian nama untuk Sang Bayi ketika pelaksanaan aqiqah hendaknya disiapkan oleh orang tua dengan pemberian nama yang baik. Hal ini dimaksudkan sebagai doa kebaikan bagi Sang Bayi (Maulidiyah, 2015) dan sebagai perlindungan untuk anak (Zaki, 2014). Terlebih lagi menurut ketentuan pemerintah, pemberian nama berperan untuk perlindungan keabsahan nasab dalam akta kelahiran (Iswanto, n.d.). Selebihnya, disunahkan mencukur rambut Sang Bayi (Azizah, 2019). Rambut cukuran ditimbang dan hasilnya, bagi yang mampu dari segi ekonomi, disetarakan dengan perak atau emassebagai sedekah untuk fakir miskin (Al-Kasyairi, 2015).

Pelaksanaan aqiqah (Asrori,1998) memiliki maknayang melimpah (Arifin, 2014), baik dari aspek filosofis (Nurnaningsih, 2013) maupun dari aspek nilai-nilai pendidikan (Azizah, 2019). Dalam hal ini, pelaksanaan aqiqah (Septianingsih, 2018) memiliki implikasi luas (Maghfuri, 2019), khususnya dalam pembentukan kepribadian anak (Rosyidah,2006). Palingutama aqiqah dilaksanakan sebagai wujud rasa syukur kepada Allah Swt. (Arifin, 2014). Namun, pada saat yang sama Nabi Saw. memerintahkan untuk menghindardariwabah menular, sebagaimanahadisriwayatal-Bukhari:

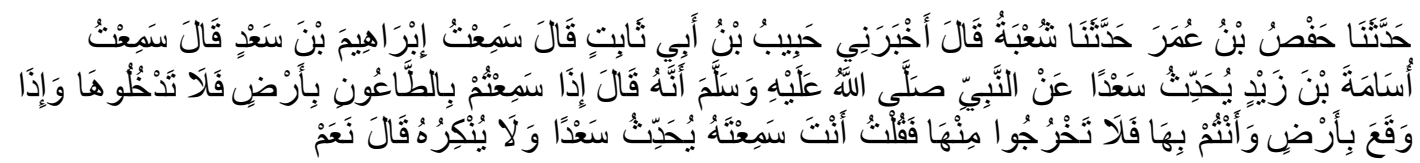

Artinya: Telah menceritakan kepada kami Hafsh bin Umar, telah menceritakan kepada kami Syu'bah, dia berkata: telah mengabarkan kepadaku Habib bin Abu Tsabit, dia berkata: saya mendengar Ibrahim bin Sa'd, berkata: saya mendengar Usamah bin Zaid, bercerita kepada Sa'd dari 


\section{Khazanah Hukum, Vol. 2 No. 3: 100-109}

Design Thinking Hadis Hukum Pelaksanaan Aqiqah Untuk Kepatuhan pada Protokol Kesehatan Pandemi COVID-19

Wahyudin Darmalaksana

Nabi Saw. bahwa beliau bersabda: "Apabila kalian mendengar wabah lepra di suatu negeri, maka janganlah kalian masuk ke dalamnya, namun jika ia menjangkiti suatu negeri, sementara kalian berada di dalamnya, maka janganlah kalian keluar dari negeri tersebut." Lalu aku ber kata: "Apakah kamu mendengar Usamah menceritakan hal itu kepada Sa'd, sementara Sa'd tidak mengingkari perkataannya Usamah?" Ibrahim bin Sa'd berkata;"Benar" (Nasir, 1422).

Hadis ini dinilai sahih (Darmalaksana, 2020a) yang dapat ditemukan pada beberapa kitab hadis (Mardiana \& Darmalaksana, 2020) dengan redaksi dan tema yang serupa (Khaeruman et al.,2020). Hadis Nabi Saw. tentang pencegahan wabah secara tegas berkaitan dengan konsep modern tentang isolasi, karantina, dan social distancing. Isolasi adalah pemisahan orang sakitdengan penyakit menular dari orang yang tidak terinfeksi untuk melindungi orang yang tidak terinfeksi, dan bia sanya terjadi di rumah sakit (Wilder-Smith \& Freedman, 2020). Karantina berarti pembatasan pergerakan orang yang diduga telah terkena penyakit menular tetapi tidak sakit, baik karena mereka tidak terinfeksi atau karena mereka masih dalam masa inkubasi (Wilder-Smith \& Freedman, 2020). Karantina medis dianggap sebagai salah satu cara paling penting untuk mencegah penyebaran penyakit menular di zaman modern, dan hal ini sebelumnyatelah ditetapkan menuruthadis Nabi (Goje,2017). Adapun social distancing dirancang untuk mengurangi interaksi antara orang-orang dalam komunitas yang lebih luas, di mana individu mungkin tertular tetapi belum diidentifikasi sehingga belum terisolasi (Wilder-Smith \& Freedman, 2020).

Pelaksanaan aqiqah merupakan sunnah yang sangat dianjurkan di satu sisi, tetapi umat muslim diperintahkan untuk menjaga jarak sebagai preventif pencegahan wabah menular di sisi lain. Di sinilah pentingnya ide solutif untuk sikap manusia beriman dalam menghadapi Covid-19(Yono, 2020).

\section{Solusi Aqiqah Di Masa Covid-19}

Pelaksanaan aqiqah di masa pandemi Covid-19 dibutuhkan fiqih baru, praktik hukum Islam baru. Dimulai dari fiqih wanita hamil (Al-Khatib, 2016), fiqih modern (Bahammam, 2013), dan secara khusus fiqih Corona (Hasbiyallah et al., 2020). Secara teori, berdasarkan pandangan ulama bahwa maksudmaksud hukum Islam dan penerpannya sangat memungkinkan melahirkan fatwa terkait Corona (Sanusi, 2020). Dari sudut pandang hukum Islam, pendekatan kaidah fiqih dan metodologi hukum Islam (ushul alFiqh) dapat diperankan untuk penanganan Covid-19 (Keagamaan \& Shodiq, 2020). Ikhtiar memutus mata rantai persebaran Covid-19 di Indonesia dipahami sebagai justivikasi pelaksanaan maksud-maksud hukum Islam (M Hikmat et al., 2020). Berkenaan dengan pelaksanaan aqiqah di masa pandemi, terasa sekali dibutuhkan fiqih yang fleksibel (Yumni, 2020).

Amalan Islam selain bermakna fiqih, juga keimanan (Yono, 2020), spritualitas (Bustomi et al,, 2020), dan bahkan sikap keberagamaan (Dadang Darmawan et al., 2020). Dari tinjauan hukum Islam sendiri, dinyatakan pasti ada hikmah di tengah wabah virus Corona (Tasri, 2020). Meskipun hadis Nabi Saw. tidak sepesifik menujuk virus Corona (Nasir, 1422), namun pencegahan wabah penyakit menular dalam sejarah Islam memiliki relevansi dengan Covid-19 (M. R. Ridho, 2020). Di antara hikmahnya adalah diakuinya karantina medis di zaman modern sebagai salah satu cara paling penting untuk mencegah penyebaran penyakitmenular sebagai diajarkan oleh Nabi (Goje,2017). Apabila ibadah dipahami sebagai prioritas meskipun di masapandemi (Tsani \& Partono, 2020), maka dapat ditemukan solusi-solusi konkrit dari berbagai perspektif teramsuk pendekatan sains (Maliki, 2020).

Pelaksanaan aqiqah menyambut kelahiran bayi (Tsaury, 2001) dipahami sebagaiprioritas ibadah (Tsani \& Partono, 2020). Di mana aqiqah dimaknai luas meliputi keimanan (Yono, 2020), spritualitas (Bustomi et al., 2020), dan sikap keberagamaan (Dadang Darmawan etal.,2020). Ini menegaskan bahwa pelaksanaan aqiqah memungkin ditinjau dari berbagai perspektif, termasuk pendekatan design thinking 


\section{Khazanah Hukum, Vol. 2 No. 3: 100-109}

Design Thinking Hadis Hukum Pelaksanaan Aqiqah Untuk Kepatuhan pada Protokol Kesehatan Pandemi COVID-19

Wahyudin Darmalaksana

(Henriksen etal., 2017). Pendekatan design thinking merupakan perspektif baru,khususnya dalam bidang fiqih. Pendekatanini mensyaratkan beberapa komponen utama, yakni empathize, define, ideate, prototype, dan test (Steinke et al., 2018). Pelaksanaan aqiqah dengan pendekatan design thinking diarahkan untuk memperhatikan psikologi kehamilan (Susanti, 2008), religiusitas (Fridayanti, 2015), kebahagiaan (Mayasari, 2014), dan ide-ide realistik berdasarkan pemikiran yang solutif (Steinke et al., 2018). Tentu, pelaksanaan aqiqah tetap memperhatikan kepatuhan terhadap protokol kesehatan Covid-19 (Yunus \& Rezki, 2020).

Ada beberapa poin utama terkait solusi pelaksanaan aqiqah berdasarkan perspektif design thinking. Pertama, perintah agama (Islam) berkenaan dengan penyambutan kelahiran anak dan aqiqah (Tsaury, 2001) merupakan sunnahyang boleh dilaksanakan, tetapi hendaknya memperhatikan protokol kesehatan Covid-19 yang ditetapkan pemerintah (Yunus \& Rezki, 2020). Kedua, penting dirumuskan standar operasional prosedur seperti diterbitkannya fiqih Corona (Hasbiyallah et al., 2020) untuk pelaksanaan aqiqah dalam tatanan new normal (Darmalaksana, 2020c). Ketiga, prototipe pelaksanaan aqiqah dirancang melalui ide-ide baru yang menjamin terhindarnya penularan virus Corona, khususnya bagi kelompok rentan (Pradana \& Casman, 2020) yang mencakup lansia dan terutama bayi yang baru lahir (Siagian, 2020).

Keempat, ruang khusus untuk ibu dan bayi direkomendasikan untuk didesain secara memadai pada pelaksanaan aqiqah sehingga terhindar dari kerumunan sebagaimana dilarang oleh pemerintah (Solahudin etal., 2020). Kelima, jama' ah aqiqah dibatasi hanya keluarga dari lingkungan terdekat dan tidak mengundang orang dari luar kota yang merupakan wilayah zona merah terpapar Covid-19. Keenam, prosesi pencukuran rambut Sang Bayi (Azizah, 2019) hendaknya dilaksanakan secara simbolik oleh orang-orang terdekat yang ditunjuk, dan tidak serta-merta jama'ah pengajian aqiqah seluruhnya ikut menggunting rambut. Pada dasarnya mencukur rambut bayi baru lahir (Mualimin, 2015) bermakna esensial untuk kebersihan dan kesehatan kulitsehingga harusdilakukan oleh orang profesional (Al-Hasan, 1997). Ketujuh, jama'ah aqiqah wajib mengenakan masker (Elfrida \& Junaida, 2020), menjaga jarak (Wilder-Smith \& Freedman, 2020), disiapkan hand sanitizer (Soni et al., 2020) dan termometer digital untuk mengecek suhu tubuh (Crossley, 2020), danjam'aah tidak boleh lebih dari 50\% kapasitas ruangan, dan untuk diperhatikan berbagai fatwa MUI terkait protokol Covid-19 (Saeful,2020).

Kedelalan, undangan hendaknya tidak ada hidangan makan prasmanan untuk kepatuhan menjaga jarak sesuai protokol kesehatan Covid-19 (Solahudin etal., 2020), tetapi disajikan dalam bentuk nasi kotak (box), sebagaimana pembagian pasakan sembelihan hewan kambing untuk tetangga lingkungan rumah sebagai bentuk syukuran. Kesembilan, paling utama dari aqiqah bukan hiruk-pikuk ritualnya seiring dengan tatanan kehidupan baru (Darmalaksana, 2020c), melainkan esensi atau hikmah (Azizah, 2015) sebagai bentuk rasa syukur (Arifin, 2014) atas amanah dari allah Swt. dengan dikaruniai anugerah anak (Sulaiman, 2008), di mana anak diakui merupakan penyejuk hati (QS: Al-Furqan: 74), juga bentuk kebahagiaan sebagai fitrah manusia (Fuad, 2015), dan kabar gembira, khususnya permohonan doa keselamatan (A. Ridho \& Qadir, 2020).

\section{SIMPULAN}

Pelaksanaan hadis hukum berkenaan dengan amalan aqiqah di masa pandemi Covid-19 telah menghasilkan beberapa ketentuan baru sesuai kepatuhan protokol kesehatan tanpa mengabaikan kaidah hukum Islam bila diselesaikan dengan pendekatan design thinking. Di antara ketentuan baru pelaksanaan sunnah aqiqah, yakni mendesain ruang pelaksanaan aqiqah, memaknai esensikandungan sunnah aqiqah 


\section{Khazanah Hukum, Vol. 2 No. 3: 100-109}

Design Thinking Hadis Hukum Pelaksanaan Aqiqah Untuk Kepatuhan pada Protokol Kesehatan Pandemi COVID-19

Wahyudin Darmalaksana

sejalan dengan hadis pencegahan wabah menular, dan merancang pelaksanaan aqiqah sesuai harapan pasangan keluarga muslim yang dianugerahi bayi baru lahir dengan tatanan baru tanpa menghilangkan hikmah hukum Islam sebagai kepatuhan terhadap protokol kesehatan Covid-19. Hasil desain dari penelitian ini diharapkan memiliki kegunaan bagi pasangan keluarga muslim yang berniat menunaikan sunnah aqiqah ditengah pandemi Corona. Penelitian ini disadari memiliki keterbatasan sebagai ide awal dalam merancang prototipe pelaksanaan aqiqah yanglebih aman, sehingga selalu dibutuhkan desain yang benar-benar dapat menjamin tercegahnya virus Corona. Rekomendasi penelitian ini adalah pendekatan baru desain thinking dalam penelitian keagamaan Islam perlu diusulkan menjadi petimbangan untuk mengatasi berbagai masalah dengan solusi yang konkrit melalui pengujian secara terus-menerus.

\section{DAFTAR PUSTAKA}

Al-Hasan, Y. M. (1997). Pendidikan Anak dalam Islam. Terjemahan Muhammad Yusuf Harun, Yayasan Al Sofwa, Jakarta.

Al-Kasyairi, M. K. (2015). Nilai-Nilai Pendidikan dalam Hadits Ibadah Aqiqah. Al-Hikmah: Jurnal Agama Dan Ilmu Pengetahuan, 12(2), 152-162.

Al-Khatib, Y. A. (2016). Fikih Wanita Hamil. Qisthi Press.

Angkola, N. I. D. (2019). Serapan Bahasa Arab Pada Budaya Akikah. Jurnal Kajian Bahasa, 8(1), 3352.

Arifin, M. (2014). Hadits-Hadits Tentang Aqiqah (Telaah Ma'anil Hadis).

Asrori, A. M. (1998). Khitan Dan Aqiqah. Surabaya: Al-Miftah.

Azizah, N. (2015). Nilai-nilai pendidikan Islam dalam Hadis Akikah. UIN Walisongo.

Azizah, N. (2019). Nilai-Nilai Pendidikan Islam dalam Hadis-Hadis Akikah. Jurnal PROGRESS: Wahana Kreativitas Dan Intelektualitas, 7(1).

Bahammam, F. S. (2013). Fiqih Modern Praktis. Gramedia Pustaka Utama.

Bustomi, J., Sanah, S., \& Siregar, Z. U. (2020). Menyikapi wabah penyakit Covid-19 dalam bertasawuf.

Crossley, B. (2020). Troubleshoot It: Accuracy of Various Thermometer Types Is Important to Consider During the COVID-19 Pandemic. Biomedical Instrumentation \& Technology, 54(3), 228-229.

Dadang Darmawan, D., Deni Miharja, D., Roro Sri Rejeki W, R., \& Erni Isnaeniah, E. (2020). Sikap keberagamaan masyarakat muslim menghadapi wabah COVID-19. LP2M.

Darmalaksana, W. (2019). Paper Template Design Thinking Methods for Learning Hadith. Pusat Studi Data Ushuluddin UIN Sunan Gunung Djati Bandung.

Darmalaksana, W. (2020a). Corona Hadis. Fakultas Ushuluddin UINSunan Gunung Djati Bandung.

Darmalaksana, W. (2020b). Metode Penelitian Kualitatif Studi Pustaka dan Studi Lapangan. PrePrint Digital Library UIN Sunan Gunung Djati Bandung.

Darmalaksana, W. (2020c). New Normal Perspektif Sunnah Nabi Saw. Fakultas Ushuluddin UIN Sunan Gunung Djati Bandung, 1.

Darmalaksana, W. (2020d). Studi Penggunaan Analisis Pendekatan Ilmu-ilmu Sosial dalam Penelitian Hadis Metode Syarah. Khazanah Sosial, 2(3), 155-166.

Elfrida, I., \& Junaida, E. (2020). Pengetahuan dan Pemanfaatan Limbah kain Perca Menjadi Masker Sebagai Pencegahan Covid-19. BEST Journal (Biology Education, Sains and Technology), $3(2), 108-113$.

Erizal, E. (2018). Jenis Hewan untuk Aqiqah. Sakena: Jurnal Hukum Keluarga, 34(1), 81-90.

Erizal, E. (2019). Jenis Hewan untuk Aqiqah: Analisis Muthlaq dan Muqayyad Hadits dalam Ushl Fiqh. Ijtihad, 34(1).

Fauci, A. S., Lane, H. C., \& Redfield, R. R. (2020). Covid-19-navigating the uncharted. Mass Medical Soc. 


\section{Khazanah Hukum, Vol. 2 No. 3: 100-109}

Design Thinking Hadis Hukum Pelaksanaan Aqiqah Untuk Kepatuhan pada Protokol Kesehatan Pandemi COVID-19

Wahyudin Darmalaksana

Fridayanti, F. (2015). Religiusitas, Spiritualitas Dalam Kajian Psikologi dan Urgensi Perumusan Religiusitas Islam. Psympathic: Jurnal Ilmiah Psikologi, 2(2), 199-208.

Fuad, M. (2015). Psikologi kebahagiaan manusia. KOMUNIKA: Jurnal Dakwah Dan Komunikasi, 9(1), 114-132.

Galuh Abdi Sucipto, G. (2018). Hukum Aqiqah Menurut Pandangan Ibnu Hazm Dan Imam Nawawi. UIN Raden Fatah Palembang.

Goje, K. (2017). Preventative Prophetic Guidance in Infection and Quarantine. Jurnal Usuluddin, 45(2), 155-170.

Hasbiyallah, H., Suntiah, R., Ainisyifa, H., \& Fatimah, T. (2020). Fikih Corona: Studi pandangan ulama Indonesia terhadap ibadah dalam kondisi darurat Covid-19. Karya Tulis Islam Fakultas Tarbiyah Jurusan PAI.

Henriksen, D., Richardson, C., \& Mehta, R. (2017). Design thinking: A creative approach to educational problems of practice. Thinking Skills and Creativity, 26, 140-153.

Ilmiyyah, N. (2016). Pemahaman dan implementasi hadits-hadits aqiqah pada masyarakat Desa Kauman Kota Kudus. UIN Walisongo.

Iswanto, F. (n.d.). Keabsahan Nasab Berdasarkan Akta Kelahiran Menurut Hukum Islam Dan Hukum Positif. Fakultas Syariah dan Hukum Universitas Islam Negeri Syarif Hidayatu llah Jakarta.

Keagamaan, D., \& Shodiq, S. (2020). Penanganan Covid-19 Dalam Pendekatan Kaidah Fikih dan Ushul Fikih. Jurnal Al-Adalah: Jurnal Hukum Dan Politik Islam, 5(2), 100-122.

Khaeruman, B., Nur, S., Mujiyo, M., \& Rodliyana, D. (2020). Pandemi Covid-19 dan kondisi darurat: Kajian hadis tematik. UIN Sunan Gunung Djati Bandung .

M Hikmat, M., Suyatman, U., Firdaus, D., \& Suswanto, D. (2020). Implementasi Maqasid Syari'ah dalam ikhtiar memutus mata rantai persebaran Covid-19 di Indonesia. Pusat Perpustakaan UIN Sunan Gunung Djati Bandung.

Maghfuri, E. H. A. (2019). Implikasi hadis Aqiqah dalam kehidupan pada riwayat Ibnu Majah nomor indeks 3165. UIN Sunan Ampel Surabaya.

Makmun, M. (2015). Hadits Al-Bukhari Tentang Aqiqah Dalam Kitab Al-Jami'al-Shahih (Kajian Sanad dan Matan). IAIN Surakarta.

Maliki, M. (2020). Covid-19, Agama, dan Sains. MAARIF Journal, 15(1), 60-92.

Mardiana, D., \& Darmalaksana, W. (2020). Relevansi Syahid Ma'nawi dengan Peristiwa Pandemic Covid-19: Studi Matan Pendekatan Ma'anil Hadis. Jurnal Perspektif, 4(1), 12-19.

Maulidiyah, I. (2015). Hadis Tentang Pemberian Nama Yang Baik: Studi Hadis Kitan Sunan Abu Dawud Nomor Indeks 4949. UIN Sunan Ampel Surabaya.

Mayasari, R. (2014). Religiusitas Islam dan kebahagiaan (sebuah telaah dengan perspektif psikologi). Al-Munzir, 7(2), 81-100.

Mualimin, M. (2015). Nilai-Nilai Pendidikan Islam dalam Aqiqah. Al-Tadzkiyyah: Jurnal Pendidikan Islam, 6(1), 80-92.

Nasir, M. Z. ibn. (1422). al-Jami` al-Musnad al-Sahihh al-Mukhtașar min Umur Rasulillah Ṣalla Allah 'alaih wasallam wa Sunanih wa Ayyamih. Dar Tauq al-Najattle.

Nasution, N. H., \& Wijaya, W. (2020). Manajemen Masjid Pada Masa Pandemi Covid 19. Yonetim: Jurnal Manajemen Dakwah, 3(01), 84-104.

Nurnaningsih, N. H. (2013). Kajian Filosofi Aqiqah dan Udhiyah (Perspekif Alqur'an dan Sunnah). DIKTUM: Jurnal Syariah Dan Hukum, 11(2), 111-122.

Pradana, A. A., \& Casman, C. (2020). Pengaruh Kebijakan Social Distancing pada Wabah COVID - 19 terhadap Kelompok Rentan di Indonesia. Jurnal Kebijakan Kesehatan Indonesia: JKKI, 9(2), 61-67.

Restianti, H. (2013). Antara Aqiqah dan Qurban. Bandung: Titian Ilmu.

Ridho, A., \& Qadir, A. M. A. (2020). Urgensi Pemberian Kabar Gembira serta Ucapan Selamat atas Kelahiran Anak Perspektif Al-Qur'an dan Hadist. Tasyri': Jurnal Tarbiyah-Syari'ah Islamiyah, 27(1), 39-49. 


\section{Khazanah Hukum, Vol. 2 No. 3: 100-109}

Design Thinking Hadis Hukum Pelaksanaan Aqiqah Untuk Kepatuhan pada Protokol Kesehatan Pandemi COVID-19

Wahyudin Darmalaksana

Ridho, M. R. (2020). Wabah Penyakit Menular dalam Sejarah Islam dan Relevansinya dengan Covid19.JUSPI (Jurnal Sejarah Peradaban Islam), 4(1), 24-33.

Ritonga, P., \& Ritonga, P. (2013). Studi Hadis-Hadis Tentang Aqiqah . Institut Agama Islam Negeri Imam Bonjol Padang.

Rosyidah, H. (2006). Nilai-Nilai Edukatif dalam Aqiqah dan Implikasinya dalam Pembentukan Kepribadian Anak. Sripsi. Semarang: IAIN Walisongo.

Saeful, A. (2020). Menelaah Kembali Fatwa MUI Tentang Penyelenggaraan Ibadah Dalam Situasi Terjadi Wabah Covid-19. Syar'ie, 3(2), 156-171.

Said, A. F. (1995). Qurban dan aqiqah: menurutajaran Islam. Badan Bookstore.

Sanusi, A. (2020). Teori Maqoshid Syariah dan Penerpannya pada Fatwa Korona (Studi Analisis Kritis). Syakhsia: Jurnal Hukum Perdata Islam, 22(1), 1-38.

Septianingsih, N. (2018). Nilai-Nilai Pendidikan Islam Dalam Pelaksanaan Aqiqah. UIN Raden Intan Lampung.

Setiawan, E. (2020). Kamus Besar Bahasa Indonesia. Badan Pengembangan Dan Pembinaan Bahasa.

Shodiqin, A., Aziz, R., Dewi, R., \& Fitriani, P. D. (2020). Model pemberdayaan jama'ah masjid menghadapi dampak coronavirus disease (covid 19).

Siagian, T. H. (2020). Mencari Kelompok Berisiko Tinggi Terinfeksi Virus Corona Dengan Discourse Network Analysis. Jurnal Kebijakan Kesehatan Indonesia:JKKI, 9(2), 98-106.

Siregar, D. (2013). Kritik Matan Tentang Hadis-Hadis Sembelihan Aqiqah. Darul Ilmi, 1(02).

Soetari, E. (1994). Ilmu Hadits. Amal Bakti Press.

Solahudin, D., Amin, D. E. S., Sumpena, D., \& Hilman, F. A. (2020). Analisis kepemimpinan di Indonesia dalam kerangka tanggap-darurat Covid-19. Penulisan Karya Tulis Ilmiah UIN Sunan Gunung Djati Bandung Di Masa Work From Home Tahun 2020.

Soni, V. M., Singh, S., Munjal, N., \& Kataria, S. (2020). Effectiveness of hand wash and sanitizer: COVID19.

Steinke, G. H., Al-Deen, M. S., \& LaBrie, R. C. (2018). Innovating information system development methodologies with design thinking. Titel: Proceedings of the 5th Conference in Innovations in IT, Volume Nr. 5.

Suaibah, S. (1997). Nilai Hadits-Hadits Aqiqah Dalam Sunan An Nasa'i. IAIN Sunan Ampel Surabaya. Sulaiman, S. (2008). Anak adalah anugerah. Utusan Publications.

Susanti, N. N. (2008). Psikologi kehamilan.

Tasri, T. (2020). Hikmah Di Tengah Wabah Virus Corona Dalam Tinjauan Hukum Islam. Qiyas: Jurnal Hukum Islam Dan Peradilan, 5(1).

Thantowi, M. R. (1994). Fungsi al-qur'an dan as sunnah sebagai petunjukbagi manusia. IAIN Sunan Ampel Surabaya.

Tsani, E. S., \& Partono, P. (2020). Prioritas Ibadah Di Masa Pandemi. At-Ta'lim: Media Informasi Pendidikan Islam, 19(1).

Tsaury, A. (2001). Penyambutan Kelahiran anak dan Aqiqah. Ta'dib: Jurnal Pendidikan Islam, 1(2).

Tugas, T. G. (2020). Data Sebaran Covid-19. Satuan Tugas Penanganan Covid-19.

Wilder-Smith, A., \& Freedman, D. O. (2020). Isolation, quarantine, social distancing and community containment: pivotal role for old-style public health measures in the novel coronavirus (2019-nCoV) outbreak. Journal of Travel Medicine, 27(2), taaa020.

Yono, Y. (2020). Sikap Manusia Beriman Menghadapi Covid 19. Mizan: Journal of Islamic Law, 4(1). Yumni, A. (2020). Fiqih Yang Fleksibel Di Masa Pandemi. NIZHAMIYAH, 10(1).

Yunus, N. R., \& Rezki, A. (2020). Kebijakan Pemberlakuan Lock Down Sebagai Antisipasi Penyebaran Corona Virus Covid-19. Salam: Jurnal Sosial Dan Budaya Syar-I, 7(3), 227-238.

Zainuddin, C., \& Azkia, Z. (2017). Polemik Usia Hewan Aqiqah: Studi Komparasi Pendapat Imam Madzhab Hukum Islam. Mazahib, 16(2), 153-180.

Zaki, M. (2014). Perlindungan Anakdalam Perspektif Islam. ASAS, 6(2). 